\title{
Pengembangan Kompetensi Guru menggunakan Aplikasi Google Classroom pada Masa Pandemic Covid-19
}

\author{
Nurhijrah ${ }^{1}$, Syarifah Suryana ${ }^{2}$ \\ Pendidikan Kesejahteraan Keluarga, Universitas Negeri Makassar \\ Alamat dan Kota \\ ${ }^{1}$ Inurhijrah@unm.ac.id, ${ }^{2}$ syarifahsuryana@unm.ac.id
}

\begin{abstract}
The development of teacher competency in using google classroom during the pvidemic covid_19 aims to develop teacher competency in managing online classes using the google classroom application, the method used in this research is the research and development (R\&D) method that refers to the ADDIE model with the subject The trial was a teacher at Garudaya Bontonompo Middle School. The results showed an increase in the competency of Garudaya SMKS teachers in using the google classroom application by looking at improvements in each assessment indicator that on average were in the very competent criteria after conducting the pretest and posttest.
\end{abstract}

Keywords: Google classroom, Kompetensi guru.

\section{PENDAHULUAN}

A. Latar Belakang

Negara Indonesia sampai saat ini masih bergelut dalam melawan COVID-19, virus ini menyebar dengan sangat cepat dan hampir tidak ada negara atau wilayah di dunia yang tidak terkena dampak COVID-19. Banyaknya kasus penyebaran yang terjadi membuat beberapa negara didunia mengambil langkah-langkah pencegahan dengan menerapkan beberapa kebijakan, salah satunya adalah lockdown, sebagai contoh negara yang menerapkan lockdown adalah negara Cina, hingga negara-negara barat seperti Italia dan Inggris.

Pemerintah Indonesia, belum mengambil langkah kebijakan lockdown karena dapat berimplikasi pada beberapa sektor kehidupan masyarakat, baik dari segi ekonomi, sosial dan keamanan. Padahal jika melihat dari penyebaran virus yang terjadi, lockdown dianggap efektif untuk diterapkan di Indonesia untuk mencegah masuknya virus yang berasal dari luar negeri. Kebijakan yang diambil oleh pemerintah untuk pencegahan penyebaran virus COVID-19 adalah dengan menerapkan pembatasan sosial (social distancing) meskipun kebijakan tersebut dianggap masih kurang efektif untuk diterapkan karena masih banyak masyarakat yang tidak mau mengikuti aturan tersebut.

Pada umumnya, dalam proses pembelajaran dibutuhkan suatu metode atau yang dapat menyalurkan pesan yang oleh pemberi pesan disampaikan kepada penerima pesan. Dalam proses tersebut, komunikasi harus berjalan dengan jelas sehingga pesan yang ingin disampaikan oleh pendidik dapat diterima dengan baik dan semestinya oleh peserta didik. Namun proses penyampaian pesan ini seringkali terjadi gangguan yang mengakibatkan pesan pembelajaran tidak diterima oleh peserta didik seperti apa yang dimaksud oleh pendidik.
Kebijakan social distancing yang diterapkan oleh pemerintah juga memberi dampak pada sektor kehidupan, sektor ekonomi merupakan sektor yang paling berpengaruh karena melibatkan seluruh lapisan masyarakat tanpa terkecuali, begitupun pada sektor pendidikan.

Pemerintah Indonesia dalam menerapkan kebijakan social distancing ikut mempengaruhi dunia pendidikan. Menteri Pendidikan dan Kebudayaan menerbitkan surat edaran 24 Maret 2020 yang mengatur pelaksanaan pendidikan pada masa darurat penyebaran corona virus [1]. Keputusan pemerintah dengan memindahkan proses belajar mengajar menjadi di rumah membuat berbagai pihak menjadi panik. Faktor utama kepanikan ini adalah ketidaksiapan sekolah dalam melaksanakan pembelajaran sistem daring. Peralihan pelaksanaan pembelajaran membuat pemanfaatan teknologi sebagai pilihan untuk memperlancar proses pembelajaran dengan sistem daring. Tapi, pada kenyataannya masih terdapat beberapa hambatan dalam pemanfaatan teknologi untuk menunjang proses pembelajaran salah satunya adalah kompetensi guru dalam penguasaan teknologi yang masih tergolong rendah.

Permasalahan yang banyak terjadi dalam bidang pendidikan pada masa pandemic COVID-19 yang menuntut pembelajaran di rumah adalah minimnya kompetensi guru dalam memanfaatkan teknologi sebagai penunjang proses pembelajaran. Sedangkan pada hakikatnya seorang guru dituntut untuk terus meningkatkan kompetensi dalam hal pendidikan dan pengajaran. Didalam Undang-undang Republik Indonesia Nomor 14 Tahun 2005 tentang Guru dan Dosen pasal 10 ayat 1 dan 2 tentang kompetensi guru yang selanjutnya diatur dalam peraturan pemerintah PP No 74 Tahun 2008 mengamanatkan bahwa setiap "Guru mampu merencanakan pembelajaran, mengevaluasi hasil belajar dan menggunakan teknologi komunikasi dan informasi 
baik pada domain kompetensi pedagogik, kompetensi kepribadian, kompetensi sosial dan kompetensi professional" [2]. Mutu sumber daya manusia selalu berhubungan dengan pengembangan kompetensi guru, sedangkan pendidikan selalu sejalan dengan perkembangan teknologi dan manusia.

Berdasarkan hasil observasi, kompetensi guru-guru di SMKS Garudaya dalam mengelola pembelajaran daring masih minim. Hal ini disebabkan karena tidak semua guru melek akan teknologi terutama guru yang lahir pada era tahun 1980 kebawah dimana pada masa mereka penggunaan teknologi belum berkembang seperti sekarang ini. Pembelajaran daring sangat berkembang pesat, hal ini didukung oleh pekembangan teknologi yang canggih, konektivitas internet, serta pasar yang sangat besar. Pembelajaran daring sangatlah populer terutama karena sifatnya yang fleksibilitas, aksesibilitas serta terjangkau bagi orang-orang yang tidak dapat memperoleh pendidikan karena jarak fisik dan konflik jadwal. Namun, pembelajaran daring tidak dapat menggantikan peran seorang guru sepenuhnya di dalam kelas [3]

Proses pembelajaran daring dapat diterapkan dengan menggunakan beberapa fasilitas teknologi seperti whatsapp, google classroom, moodle, lms dan sebagainya. Guru SMKS Garudaya telah melaksanakan pembelajaran daring pada awal pembelajaran dengan menggunakan aplikasi whatsapp, namun seiring berjalannya waktu, pembelajaran dengan menggunakan whatsapp memiliki beberapa kekurangan salah satunya adalah tugas-tugas dan materi yang diberikan tidak dapat diatur secara sistematis termasuk teknis pengumpulan tugas yang tdk dapat diberikan batas waktu pengumpulan.

Guru SMKS Garudaya Bontonompo memerlukan pengembangan kompetensi dalam mengelola pembelajaran secara online dengan mengikuti pelatihan yang mampu meningkatkan kemampuan mengelola pembelajaran online yang lebih efektif dan sistematis dalam pelaksaannya, salah satunya adalah dengan menggunakan aplikasi google classroom.

Kompetensi adalah kombinasi antara pengetahuan, keterampilan, dan perilaku yang digunakan untuk meningkatkan kinerja, keadaan serta kualitas yang memadai atau sangat berkualitas, mempunyai kemampuan untuk menampilkan peran tertentu [4]. Kompetensi merupakan kemampuan seseorang yang meliputi pengetahuan, keterampilan, dan sikap yang dapat diwujudkan dalam hasil kerja nyata yang bermanfaat bagi diri dan lingkungannya [5]. Sedangkan menurut Kartowagiran, Kompetensi guru adalah kemampuan yang harus dimiliki guru dalam perencanaan dan pelaksanaan proses pembelajaran. Kompetensi guru memegang peranan dalam peningkatan mutu pendidikan karena di tangan guru kurikulum, sumber belajar, sarana dan prasarana, iklim pembelajaran menjadi sesuatu yang berarti bagi kehidupan peserta didik [6].

Tugas seorang guru bukan hanya melaksanakan kegiatan belajar mengajar tetapi juga senantiasa meningkatkan kompetensi yang dimiliki dengan menambah ilmu serta pengetahuan melalui berbagai kegiatan baik itu penataran, pelatihan, seminar loka karya maupun diskusi dalam kelompok MGMP [7].

Google classroom adalah aplikasi yang dibuat untuk mempermudah dosen dan mahasiswa dalam pembelajaran apabila berhalangan. Dalam mengorganisasi dan berkomunikasi dengan mahasiswa tidak terikat dengan jadwal perkuliahan di kelas, serta dapat membantu dosen dalam pemberian tugas dan nilai kepada mahasiswa [8]. Aplikasi google classroom telah banyak digunakan sebagai penunjang dalam proses pembelajaran selain itu aplikasi ini sangat mudah digunakan karena dapat diakses oleh semua orang [9].

Metode pembelajaran online dengan menggunakan google classroom adalah metode pembelajaran yang mempermudah guru dalam mengelola kelas online, membuat tugas tanpa menggunakan kertas, serta siswa dapat belajar, menyimak, membaca dan mengirimkan tugas dari jarak jauh [10]. Beberapa kelebihan yang dimiliki google classroom adalah dapat merampingkan komunikasi dan alur kerja siswa, file tugas menjadi lebih teratur, dapat dengan mudah melacak siswa yang mengalami kesulitan serta proses penilain yang mudah [11].

Tujuan dari penelitian ini adalah untuk mengembangkan kompetensi guru dalam menggunakan aplikasi google classroom pada masa pandemic COVID-19. Manfaat penelitian adalah dapat menambah ilmu pengetahuan dibidang pendidikan khususnya dalam peningkatan keterampilan menggunakan aplikasi google classroom, sebagai bahan acuan bagi setiap pengajar dalam melaksanakan proses pembelajaran.

\section{METODE}

Penelitian ini merupakan penelitian R \& D (Research and Development) yang mengacu pada model ADDIE. Adapun tahapan penelitian antara lain:

A. Analysis

Pada tahap analysis terdapat 2 tahap kegiatan yang akan dilaksanakan yaitu:

1. Tahap pertama adalah analisis kinerja, pada tahapan ini peneliti melakukan analisis masalah kinerja dan menentukan solusi yang akan diambil terhadap masalah tersebut.

2. Tahap kedua adalah analisis kebutuhan (need analysis), pada langkah ini peneliti menganalisis kebutuhan yang diperlukan oleh peserta untuk menentukan kemampuan atau kompetensi yang akan dicapai.

Setelah kedua kegiatan tahap analisis dilaksanakan, selanjutnya akan masuk pada tahap beriktunya yaitu pada tahap design.

B. Design

Tahap desain pada penelitian ini meliputi beberapa kegiatan sebelum masuk dalam tahap pengembangan. Adapun tahapan desain antara lain:

1. Menentukan kebutuhan pembelajar 
2. Merumuskan tujuan pembelajaran yang akan dicapai dalam kegiatan ini.

3. Melaksanakan pelatihan

C. Development

Pada tahap pengembangan yaitu membuat scenario kegiatan pembelajaran dan panduan penggunaan aplikasi google classroom. Penyampaian isi atau materi pelatihan dari fasilitator akan dilaksanakan secara online. Sebelum melaksanakan peltihan terlebih dahulu produk yang dihasilkan di lakukan validasi oleh validator, sehinnga sebelum diterapkan pada guru SMKS Garudaya dapat dilakukan revisi dan perbaikan pada perangkat pelatihan.

D. Implementation

Langkah selanjutnya adalah melaksanakan tahap implementasi yaitu merealisasikan pelatihan penggunaan aplikasi google classroom untuk meningkatkan kompetensi guru dalam mengelola kelas daring pada masa pandemic COVID-19. Lokasi penelitian dilaksanakan di SMKS Garudaya dengan subjek penelitian adalah guru-guru di SMKS Garudaya. Data yang digunakan dalam penelitian ini berupa data kuantitatif dan kualitatif.

E. Evaluation

Pada tahap evaluasi diambil dari hasil uji coba lapangan yang dilaksanakan di SMKS Garudaya yaitu hasil pretest dan postest yang dilaksanakan sebelum dan sesudah melaksanakan pelatihan.

\section{HASIL DAN PEMBAHASAN}

Penelitian ini merupakan penelitian $\mathrm{R}$ \& $\mathrm{D}$ yang mengacu pada model ADDIE yang bertujuan untuk meningkatkan kompetensi guru dalam menggunakan aplikasi google classroom. Beberapa hal yang menjadi tolak ukur pada hasil penelitian adalah ketercapaian tujuan penelitian. Adapun indikator ketercapaian tujuan penelitian dapat diketahui dari hasil pembahasan sebagai berikut:

\section{A. Analysis}

Pada tahap ini kegiatan utama adalah (1) menganalisis kinerja, yaitu melakukan klarifikasi masalah kinerja yang dihadapi di SMKS Garudaya dengan memberikan solusi berupa penyelenggaraan program pelatihan menggunakan aplikasi google classroom pada masa pandemic COVID-19 dalam mengelola pembelajaran daring (2) menganalisis kebutuhan yang diperlukan untuk menentukan kompetensi yang dibutuhkan oleh Guru SMKS Garudaya untuk meningkatkan kinerja. Berdasarkan hasil pemantauan dan pengamatan yang dilakukan diperoleh informasi bahwa hampir sebagian besar guru SMKS Garudaya belum mengetahui pengunaan aplikasi Google Clasroom.

\section{B. Design}

Rancangan model pelatihan menggunakan aplikasi google classroom pada masa pandemic COVID-19 dalam mengelola pembelajaran daring menggunakan 3 tahapan model CEM. Tujuan pada tahap ini adalah untuk mempersiapkan desain model pelatihan yang akan diimplementasikan pada guru SMKS Garudaya. Tahap ini meliputi: menentukan kebutuhan pembelajar, merumuskan tujuan pembelajaran dan melaksanakan pelatihan.

\section{Development}

Tahap pengembangan pada penelitian ini adalah:

1) Pengembangan Model Pelatihan: kegiatan yang dilaksanakan pada tahap ini adalah realisasi rancangan produk, meliputi penyusunan skenario kegiatan pembelajaran, penyusunan panduan penggunaan google classroom serta perangkat evaluasi.

2) Rancangan Model Awal: Pada tahap ini meliputi Pertama, Komponen model yaitu keterlibatan peserta pelatihan dalam hal ini guru SMKS Garudaya. Keikutsertaan peserta memiliki peran yang sangat penting dalam kegiatan perencanaan, pelaksanaan kegiatan dan taha evaluasi. Kedua, Isi model yaitu lebih diarahkan pada proses pelatihan berupa penentuan materi pembelajaran dan metode serta teknik yang digunakan. Ketiga, proses model meliputi pelaksanaan pelatihan, dan evaluasi program pelatihan dimana prosesnya dilaksanakan dengan memberikan teori dan praktik. Keempat, Model pelatihan dikembangkan untuk mengetahui peningkatan kompetensi guru SMKS Garudaya dalam memngelola pembelajaran daring menggunakan google classroom.

3) Validasi Produk Pelatihan: Hasil validasi produk berupa skenario kegiatan pembelajaran berada pada rerata 4.46 dan untuk panduan penggunaan google classroom berada pada rerata 4.33 yang berada pada kategori valid dapat dilihat pada diagram dibawah ini.

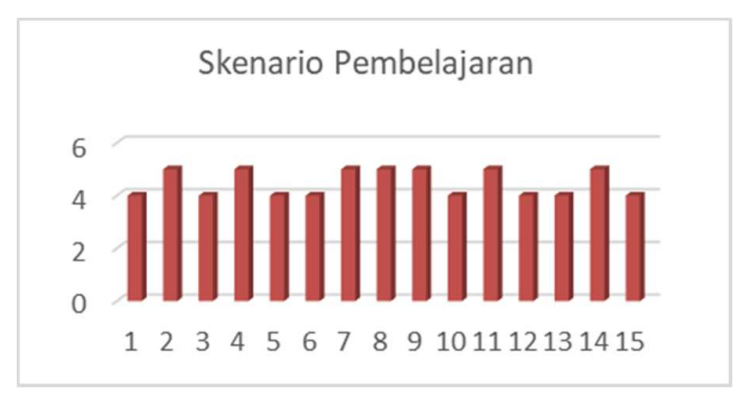

Gambar 1. Diagram batang hasil validasi produk berupa skenario pembelajaran

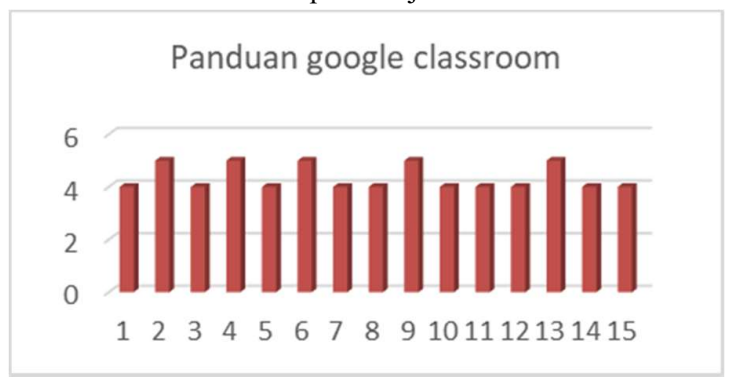

Gambar 2. Diagram batang hasil validasi produk berupa panduan google classroom 
D. Implemention

Tahap implementasi dilakukan dengan melaksanakan pelatihan secara online untuk mengembangkan kompetensi guru dalam menggunakan aplikasi google clasroom dalam mengelola pembelajaran daring. Kegitan ini melibatkan sebanyak 25 orang guru pada SMKS Garudaya.

Sebelum melaksanakan pelatihan secara online terlebih dahulu diberikan pretest untuk mengetahui kemampuan awal guru dalam penggunaan aplikasi google classroom. Berikut ini adalah beberapa indikator penilaian dalam penggunaan aplikasi google classroom.

1) Kemampuan untuk membuat akun: sebelum memberikan guru SMKS Garudaya pelatihan penggunaan aplikasi google classroom, terlebih dahulu diberikan pretest untuk mengukur kemampuan awal dalam membuat akun pada google classroom. Hasil pretest menunjukkan bahwa penilaian terhadap kemampuan membuat akun memperoleh rata-rata 1.8 yang menunjukkan bahwa kompetensi tersebut berada pada kriteria tidak kompeten. Dapat dilihat pada grafik dibawah ini:

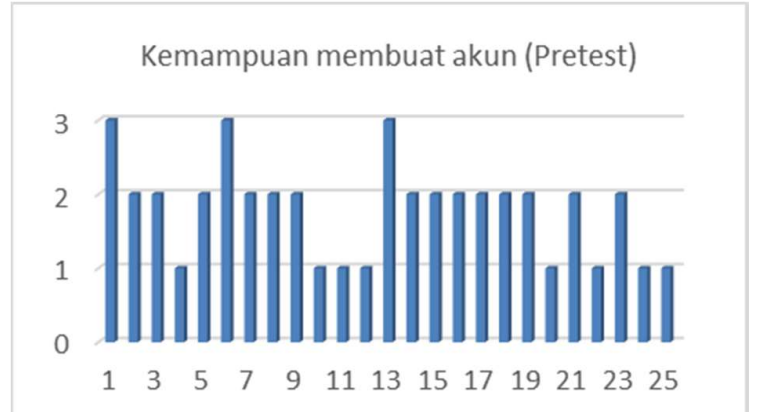

Gambar 3. Diagram batang hasil pretest kemampuan membuat akun pada google classroom

Hasil postest setelah guru-guru mendapatkan pelatihan penggunaan aplikasi google classroom dalam pembelajaran daring menunjukkan bahwa penilaian terhadap kemampuan membuat akun memperoleh rata-rata 3.48 dan mengalami perkembangan meningkat dan masuk dala kriteria sangat kompeten. Dapat dilihat pada grafik dibawah ini:

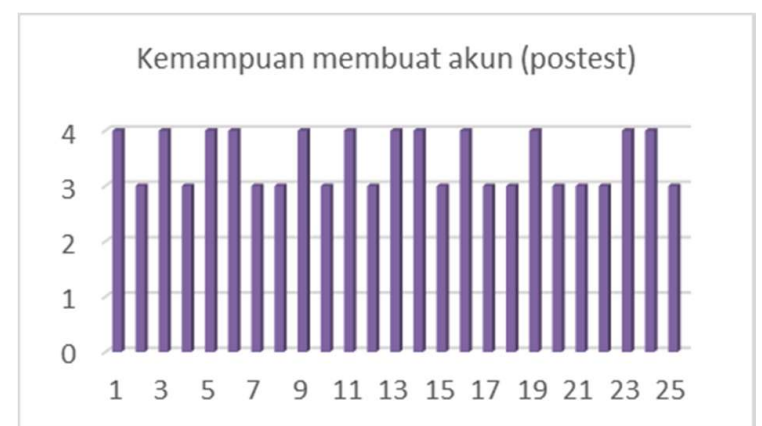

Gambar 4. Diagram batang hasil postest kemampuan membuat akun pada google classroom
2) Kemampuan membuat kelas: Kompetensi selanjutnya adalah mengukur kemampuan guru SMKS Garudaya dalam membuat kelas pada google classroom. Hasil pretest menunjukkan bahwa penilaian terhadap kemampuan membuat kelas pada aplikasi google classroom memperoleh rata-rata 1.4 yang menunjukkan bahwa kompetnsi tersebut berada pada kriteria tidak kompeten. Dapat dilihat pada grafik dibawah ini:

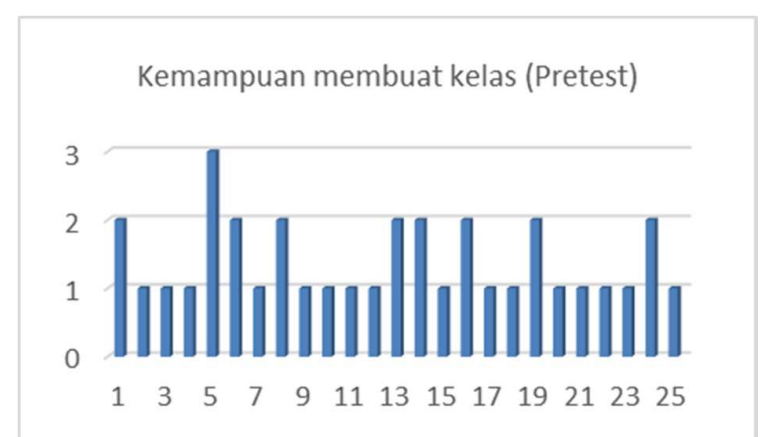

Gambar 5. Diagram batang hasil pretest kemampuan membuat kelas pada google classroom

Hasil postest setelah guru-guru mendapatkan pelatihan penggunaan aplikasi google classroom dalam pembelajaran daring menunjukkan bahwa penilaian terhadap kemampuan membuat kelas memperoleh rata-rata 3.72 dan mengalami perkembangan meningkat dan masuk dalam kriteria sangat kompeten. Dapat dilihat pada grafik dibawah ini:

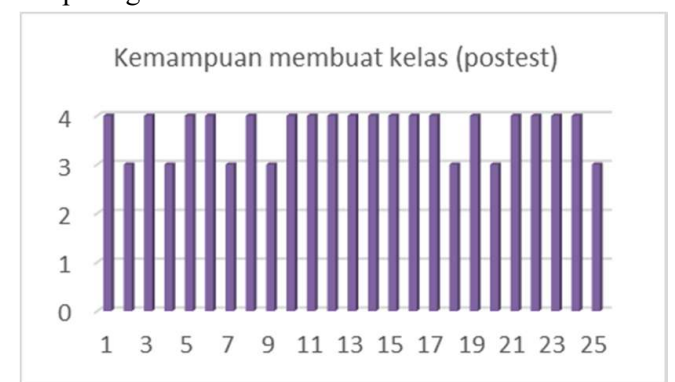

Gambar 6. Diagram batang hasil postest kemampuan membuat kelas pada google classroom

3) Kemampuan memberikan pengumuman: Kompetensi selanjutnya adalah mengukur kemampuan guru SMKS Garudaya dalam memberikan pengumuman pada google classroom. Hasil pretest menunjukkan bahwa penilaian terhadap kemampuan memberikan pengumuman pada aplikasi google classroom memperoleh rata-rata 2.04 yang menunjukkan bahwa kompetensi tersebut berada pada kriteria tidak kompeten. Dapat dilihat pada grafik dibawah ini: 
Jurnal MediaTIK : Jurnal Media Pendidikan Teknik Informatika dan Komputer

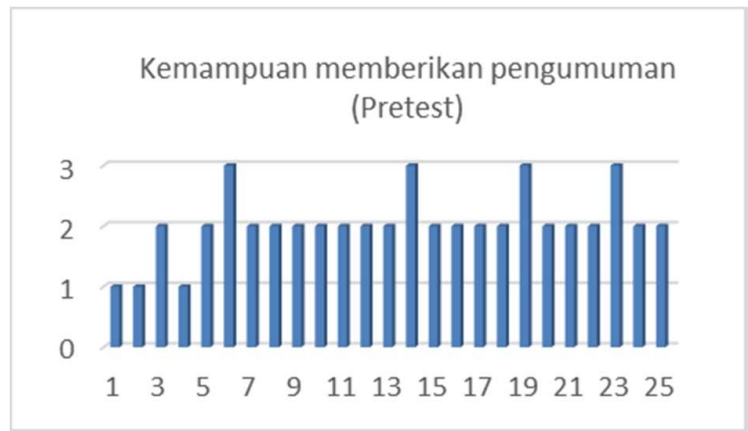

Gambar 7. Diagram batang hasil pretest kemampuan memberikan pengumuman pada google classroom

Hasil postest setelah guru-guru mendapatkan pelatihan penggunaan aplikasi google classroom dalam pembelajaran daring menunjukkan bahwa penilaian terhadap kemampuan memberikan pengumuman memperoleh rata-rata 3.88 dan mengalami perkembangan meningkat dan masuk dalam kriteria sangat kompeten. Dapat dilihat pada grafik dibawah ini:

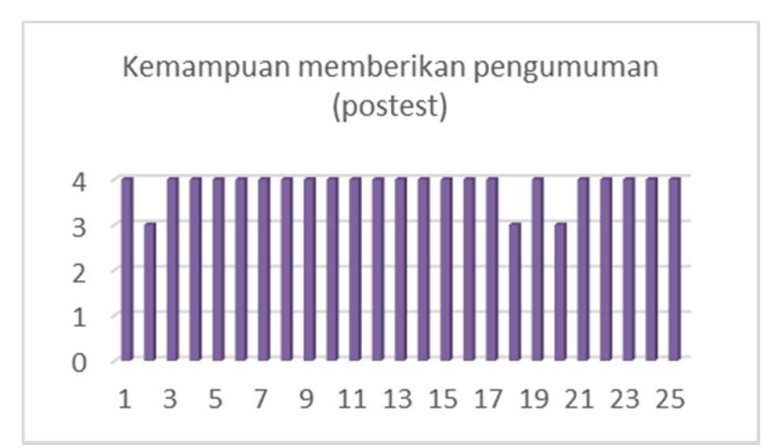

Gambar 8. Diagram batang hasil postest kemampuan memberikan pengumuman pada google classroom

4) Kemampuan memasukkan materi: Kompetensi berikutnya adalah mengukur kemampuan guru SMKS Garudaya dalam memasukkan materi. Hasil pretest menunjukkan bahwa penilaian terhadap kemampuan memasukkan materi memperoleh rata-rata 1.72 yang menunjukkan bahwa kompetensi tersebut berada pada kriteria tidak kompeten. Dapat dilihat pada grafik dibawah ini:

\section{Kemampuan memasukkan materi (Pretest)}

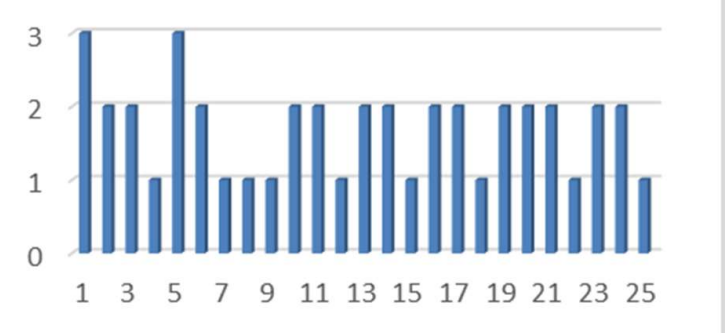

Gambar 9. Diagram batang hasil pretest kemampuan memasukkan materi pada google classroom

Hasil postest setelah guru-guru mendapatkan pelatihan penggunaan aplikasi google classroom menunjukkan bahwa penilaian terhadap kemampuan memasukkan materi memperoleh total rata-rata 3.52 dan mengalami perkembangan meningkat serta masuk dalam kriteria sangat kompeten. Dapat dilihat pada grafik dibawah ini:

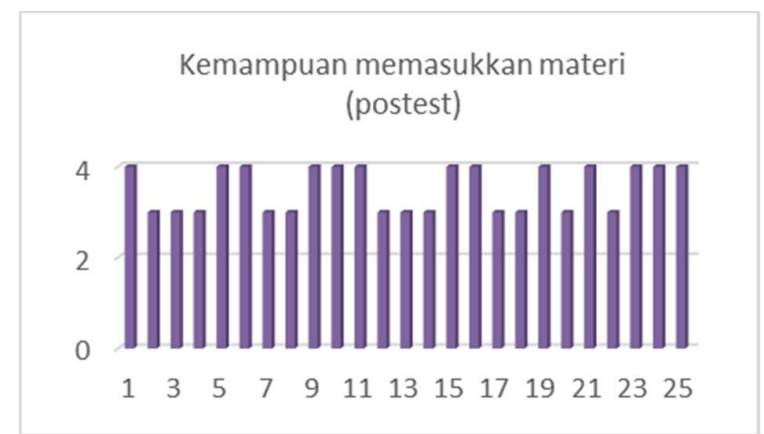

Gambar 10. Diagram batang hasil postest kemampuan memasukkan materi pada google classroom

5) Kemampuan membuat absen/presensi: Kompetensi selanjutnya yang tidak kalah penting dengan kompetensikompetensi lainnya adalah kemampuan membuat absensi/ presensi. Hasil pretest menunjukkan bahwa nilai kemampuan membuat abesnsi/ presensi berada pada ratarata 1.16 yang menunjukkan bahwa kompetensi tersebut berada pada kriteria sangat tidak kompeten. Dapat dapat dilihat pada grafik dibawah ini:

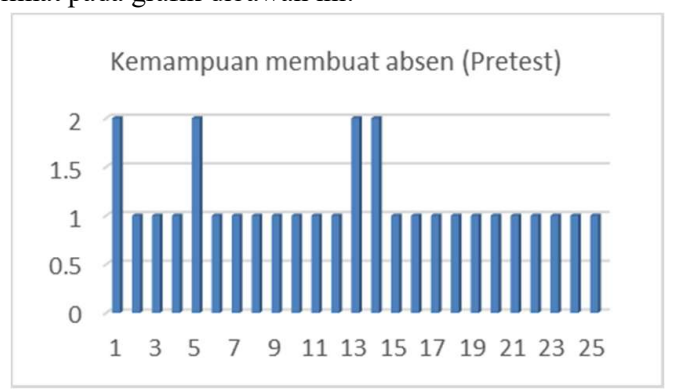

Gambar 11. Diagram batang hasil pretest kemampuan membuat absen/ presensi pada google classroom

Hasil postest setelah guru-guru mendapatkan pelatihan penggunaan aplikasi google classroom menunjukkan bahwa penilaian terhadap kemampuan membuat absen/ presensi memperoleh total rata-rata 3.6 dan mengalami perkembangan meningkat serta masuk dalam kriteria sangat kompeten. Dapat dilihat pada grafik dibawah ini: 


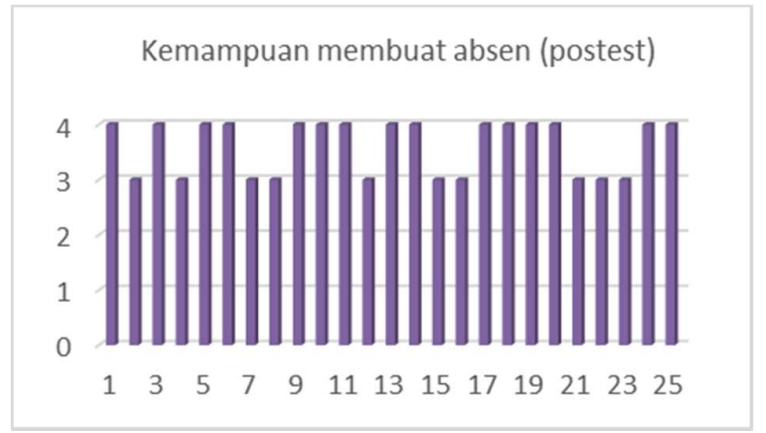

Gambar 12. Diagram batang hasil postest kemampuan membuat absen/ presensi pada google classroom

6) Kemampuan membuat tugas: Dalam menggunakan aplikasi google classroom kemampuan membuat tugas merupakan salah satu faktor kompetensi yang memberikan pengaruh. Hasil pretest menunjukkan bahwa penilaian terhadap kemampuan membuat tugas memperoleh rata-rata 1.2 yang menunjukkan bahwa kompetensi tersebut berada pada kriteria sangat tidak kompeten. Dapat dilihat pada grafik dibawah ini:

Kemampuan membuat tugas (Pretest)

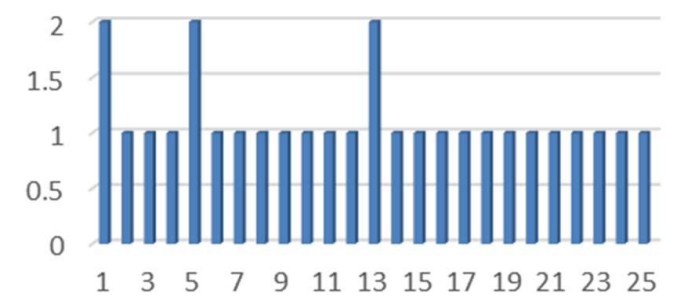

Gambar 13. Diagram batang hasil pretest kemampuan membuat tugas pada google classroom

Hasil postest setelah guru-guru mendapatkan pelatihan penggunaan aplikasi google classroom menunjukkan bahwa penilaian terhadap kemampuan membuat tugas memperoleh total rata-rata 3.72 dan mengalami perkembangan meningkat serta masuk dalam kriteria sangat kompeten. Dapat dilihat pada grafik dibawah ini:

Kemampuan membuat tugas (postest)

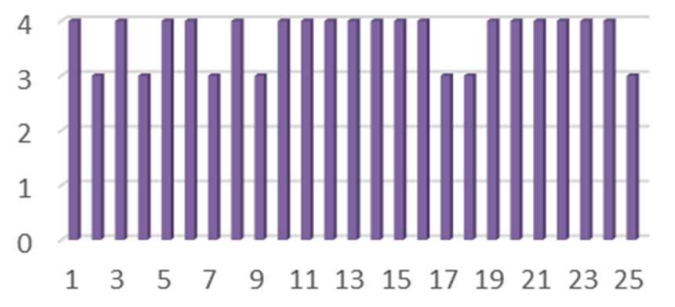

Gambar 14. Diagram batang hasil postest kemampuan membuat tugas pada google classroom
7) Kemampuan membuat quiz: Kompetensi akhir yang harus dipahami dalam penggunaan aplikasi google classroom adalah kemampuan membuat quiz, merupakan salah satu faktor kompetensi yang memberikan pengaruh. Hasil pretest menunjukkan bahwa penilaian terhadap kemampuan membuat quiz memperoleh rata-rata 1.08 yang menunjukkan bahwa kompetensi tersebut berada pada kriteria sangat tidak kompeten. Dapat dilihat pada grafik dibawah ini:

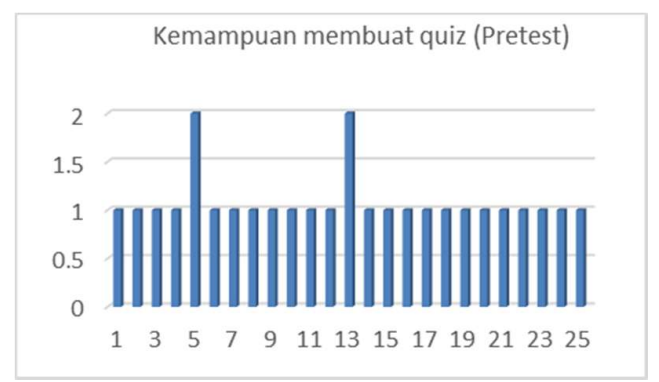

Gambar 15. Diagram batang hasil pretest kemampuan membuat quiz pada google classroom

Hasil postest setelah guru-guru mendapatkan pelatihan penggunaan aplikasi google classroom menunjukkan bahwa penilaian terhadap kemampuan membuat quiz memperoleh total rata-rata 3.48 dan mengalami perkembangan meningkat serta masuk dalam kriteria sangat kompeten. Dapat dilihat pada grafik dibawah ini:

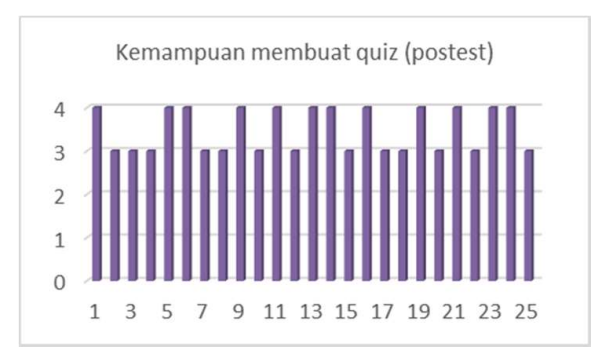

Gambar 16. Diagram batang hasil postest kemampuan membuat quiz pada google classroom

E. Evaluation

Setelah dilakukan uji coba, tahap selanjutnya adalah mempelajari apakah pengembangan kompetensi guru SMKS Garudaya sudah sesuai dengan tujuan yang ditentukan sebelumnya dalam hal ini meningkatkan kompetensi guru dalam menggunakan aplikasi google classroom pada masa pandemic-19. Tahap evaluasi ini terdiri dari evaluasi formatif yang di ambil dari hasil pretest dan postest yang dilaksanakan di SMKS Garudaya yaitu hasil belajar guru dalam menggunakan aplikasi google classroom sebelum dan sesudah mengikuti pelatihan.

\section{KESIMPULAN}

Pengembangan Kompetensi Guru menggunakan Aplikasi Google Classroom pada Masa Pandemic Covid-19 adalah 
penelitian pengembangan (R\&D), yang mengacu pada model pengembangan ADDIE yaitu: Analysis, Design, Development, Implementation, Evaluation. Hasil penelitian menunjukkan adanya peningkatan kompetensi guru SMKS Garudaya dalam menggunakan aplikasi google classroom dengan melihat peningkatan dalam setiap indikator penilaian yang rata-rata berada pada kriteria sangat kompeten setelah melakukan pretest dan postest.

Ucapan terimaksih yang sebesar-besarnya kepada Universitas Negeri Makassar yang telah memberikan dukungan dalam pelaksanaan penelitian ini. Tak lupa pula penulis mengucapkan terimakasih kepada seluruh elemen di SMKS Garudaya yang telah memberikan dukungan dan bantuan mulai dari tahap pelaksanaan hingga penyelesaian penelitian ini.

\section{DAFTAR PUSTAKA}

[1] Pengelola web Kemdikbud, "SE Mendikbud: Pelaksanaan Kebijakan Pendidikan dalam Masa Darurat Penyebaran Covid19," 2020. https://www.kemdikbud.go.id/main/blog/2020/03/semendikbud-pelaksanaan-kebijakan-pendidikan-dalam-masadarurat-penyebaran-covid19.

[2] Undang-Undang Republik Indonesia Nomor 14 Tahun 2005 Tentang Guru Dan Dosen. Jakarta: Sinar Grafika, 2014.

[3] A. Sun and X. Chen, "Online education and its effective practice: A research review,” J. Inf. Technol. Educ. Res., vol. 15, no. 2016, pp. 157-190, 2016, doi: 10.28945/3502.

[4] A. Suparman, Desain Instruksional Modern. Jakarta: Erlangga, 2012.

[5] J. Musfah, Peningkatan Kompetensi Guru. Jakarta: Kencana Prenada Media Group, 2012.

[6] B. Kartowagiran, "KINERJA GURU PROFESIONAL (GURU PASCA SERTIFIKASI)," J. Cakrawala Pendidik., 2015, doi: 10.21831/cp.v3i3.4208.

[7] A. Cahyana, "Pengembangan Kompetensi Profesional Guru dalam Menghadapi Sertifikasi," J. Pendidik. dan Kebud., 2010, doi: 10.24832/jpnk.v16i1.434.

[8] Sabran and E. Sabara, "Keefektifan Google Classroom sebagai media pembelajaran," Pros. Semin. Nas. Lemb. Penelit. Univ. NEGERI Makasar, 2019.

[9] N. Maharani and K. S. Kartini, "Penggunaan google classroom sebagai pengembangan kelas virtual dalam keterampilan pemecahan masalah topik kinematika pada mahasiswa jurusan sistem komputer," PENDIPA J. Sci. Educ., 2019, doi: 10.33369/pendipa.3.3.167-173.

[10] Soni et al., "Optimalisasi Pemanfaatan Google Classroom Sebagai Media Pembelajaran Di SMK Negeri 1 Bangkinang," J. Pengabdi. Untuk Mu NegeRI, 2018.

[11] Iftakhar Shampa, "Google classroom: What works and how?," J. Educ. Soc. Sci., 2016. 